Jurnal Pemikiran Sosiologi Volume 5 No. 2, Agustus 2018

\title{
Jogjaplan dan Kelompok Warga Pengawal Anggaran dalam Perencanaan Pembangunan di Daerah Istimewa Yogyakarta 1
}

Anggalih Bayu Muh. Kamim, M. Rusmul Khandiq, dan Ichlasul Amal2

Abstraksi

Daerah Istimewa Yogyakarta memiliki platform Jogjaplan yang ditujukan untuk perencanaan awal dan usulan perencanaan anggaran pembangunan. Evaluasi terhadap pemanfaatan platform Jogjaplan perlu dilakukan untuk memastikan adanya partisipasi warga DIY dalam proses perencanaan anggaran dan evaluasi pembangunan. Kajian ini menggunakan pendekatan participatory budgeting yang berusaha mendorong pelibatan warga secara aktif dalam seluruh siklus penganggaran. Penelitian dilakukan dengan metode penelitian kualitatif deskriptif untuk melakukan evaluasi terhadap pemanfaatan Jogjaplan dalam perencanaan anggaran di DIY dan kehadiran Kelompok Warga Pengawal Anggaran (KWPA). Analisis data dilakukan melalui tahap reduksi data, penyajian data, verifikasi dan penarikan kesimpulan. Hasil penelitian menunjukkan bahwa pemanfaatan platform Jogjaplan lebih ditujukan untuk transparansi pembangunan secara formal yang melibatkan kinerja Satuan Kerja Pemerintah Daerah (SKPD), tetapi belum sepenuhnya melibatkan proses partisipasi warga khususnya dalam praktik penganggaran berbasis partisipasi.

Kata kunci: Jogjaplan, platform pembangunan, perencanaan anggaran daerah, evaluasi pembangunan daerah, partisipasi warga, penganggaran berbasis partisipasi.

\begin{abstract}
The Special Region of Yogyakarta has a platform called "Jogjaplan" intended for development planning and development budget planning. An evaluation of the use of the Jogjaplan platform is necessary due to the need for citizens'participation in the budget planning process. This study uses a participatory budgeting approach that seeks to encourage active citizen involvement in the entire budgeting cycle. The study was conducted by a descriptive qualitative research method to evaluate the use of Jogjaplan for budget planning in the provice and the presence of a collective citizens' participatory group named 'Kelompok Warga Pengawal Anggaran' (KWPA). Data analysis is conducted through several steps that include; data reduction, data presentation, verification, and conclusion. The research shows that the utilization of the Jogjaplan platform is aimed more at a formal transparency of regional development that synchronize the work of the Regional Government Units (SKPD), but lacking support from citizens' participation especially in the practice of participatory budgetting.
\end{abstract}

Keywords: Jogjaplan, development platform, regional budgeting plan, development evaluation, citizens' participation, participatory budgetting.

1Untuk mengutip artikel: Kamim. Muh, Anggalih Bayu, Khandiq, dan Amal. 2018.”Jogjaplan dan Kelompok Warga Pengawal Anggaran dalam Perencanaan Pembangunan di Daerah Istimewa Yogyakarta." Jurnal Pemikiran Sosiologi 5 (2): 27-53.

2Tim peneliti Departemen Politik dan Pemerintahan, Fakultas Ilmu Sosial dan Ilmu Politik, UGM. Contact: (1) anggalih.bayu@yahoo.co.id (2) m.r.khandiq@gmail.com (3) ichlasulamal4@gmail.com 
Jurnal Pemikiran Sosiologi Volume 5 No. 2, 2018

Jogjaplan dan Kelompok Warga Pengawal Anggaran dalam Perencanaan Pembangunan

di Daerah Istimewa Yogyakarta

Anggalih Bayu Muh. M. Rusmul Khandiq, Ichlasul Amal

\section{A. Pendahuluan}

Kajian ini ditujukan untuk menelisik pemanfaatan Jogjaplan dalam perencanaan anggaran dan pembangunan di DIY yang sudah muncul semenjak tahun 2011 dan diinisiasi oleh Bappeda DIY. Pendalaman terhadap Jogjaplan menjadi menarik untuk melihat adanya kelemahan yang muncul dari pemanfaatannya. Jogjaplan ternyata dihadapkan pada tantangan berupa proses perencanaan pembangunan yang masih terkesan birokratis dan belum mampu mewadahi partisipasi warga secara aktif dalam perencanaan anggaran dan pembangunan. Jogjaplan sendiri adalah sebuah alat penyusunan RKPD, KUA PPAS, KUA/PPAS Perubahan, RKPD Perubahan agar dapat terselesaikan dengan mudah, cepat, tepat dan sesuai dengan kebijakan dan aturan yang berlaku. Dengan adanya Jogjaplan, Bappeda diharapkan dapat memaksimalkan sistem dan sistem juga mampu menyajikan analisa yang sangat informatif bagi para pemangku kepentingan.

Jogjaplan didorong sarana penyampai informasi akuntabilitas kinerja dan penggunaan anggaran termasuk Dana Keistimewaan yang digunakan oleh Bappeda DIY. Akuntabilitas kinerja di DIY didahului oleh pelaksanaan monitoring dan evaluasi melalui aplikasi monev, dilanjutkan dengan analisis data melalui aplikasi Decission Support System (DSS). Kemudian disinergikan dengan potret kemiskinan yang diakses melalui aplikasi kemiskinan. Sistematisasi dan otomatisasi sistem akuntabilitas kinerja tersebut diklaim diperlukan untuk memaksa pegawai untuk bekerja sesuai sistem, sehingga ada kepatuhan dari semua komponen dalam tata kelola pemerintahan. Di sisi yang lain, dalam rangka meningkatkan daya ungkit terhadap investasi dan perekonomian daerah, DIY juga melakukan simplifikasi berbagai kegiatan. Ditambahkan, ukuran keberhasilan kinerja SKPD di DIY adalah seberapa besar efisiensi anggaran, kepatuhan dalam tata kelola, serta pencapaian Indikator Kinerja Utama.

Penerapan e-goverment, e-budgeting dan money follow program selama ini dibuat dengan instrumen yang didasarkan pada skala kebutuhan dan berorientasi pada hasil. Saat menyusun anggaran, sasaran kerja dibuat terukur. Program yang dijalankan harus sesuai skala prioritas yang berorientasi pada hasil kualitas. Upaya integrasi melalui pelaksanaan program juga didorong dengan adanya Jogjaplan. Penggunaan Jogjaplan juga membuat Pemda DIY mengurangi jumlah rapat, perjalanan dinas dan belanja negara untuk efisiensi anggaran. Hasil laporan kinerja Pemda bisa diakases publik melalui aplikasi dan web. 
Jurnal Pemikiran Sosiologi Volume 5 No. 2, 2018

Jogjaplan dan Kelompok Warga Pengawal Anggaran dalam Perencanaan Pembangunan

di Daerah Istimewa Yogyakarta

Anggalih Bayu Muh. Kamim, M. Rusmul Khandiq, Ichlasul Amal.

Namun, penggunaan Jogjaplan dalam perencanaan anggaran dan pembangunan di DIY dihadapkan pada hambatan dan kelemahan yang muncul. Salah satu penyebab belum maksimalnya pemanfaatan Jogjaplan.com adalah kurangnya sosialisasi kepada masyarakat. Hal ini berujung pada kenyataan bahwa pihak-pihak yang mengakses website ini terbatas pada kalangan tertentu saja. Padahal Pemda DIY berharap bahwa masyarakat bisa turut serta berperan dalam menyusun rencana alokasi Danais lewat usulan program, yang bahkan, bisa menyasar sampai tingkat desa dan dusun. Kurangnya sosialisasi dan edukasi terhadap keberadaan dan fungsi Jogjaplan menjadi penyebab kurang maksimalnya pemanfaatan terhadap website ini. Padahal Pemda DIY berharap tidak ada lagi masyarakat yang tidak mengetahui tentang program keistimewaan. Hal tersebut tak lepas dari keluhan masyarakat yang sering menganggap bahwa program keistimewaan tidak sampai ke level desa dan dusun. Dibutuhkan suatu inovasi untuk mengatasi kelemahan yang muncul akibat minimnya partisipasi masyarakat dalam penggunaan Jogjaplan dalam perencanaan anggaran dan pembangunan DIY. Partisipasi masyarakat dalam pembangunan DIY penting diperkuat untuk memastikan bahwa penggunaan anggaran dan rencana pembangunan benar-benar sesuai dengan kebutuhan warga dan menyelesaikan masalah yang dihadapi di lapangan, tidak terbatas pada penggunaan layanan informasi daring. Penggunaan layanan daring seperti Jogjaplan dihadapkan pada tantangan masyarakat yang perlu melek digital dan paham proses kebijakan publik.

Hadirnya kelompok masyarakat yang pro aktif dan memiliki pemahaman yang baik tentang proses kebijakan publik untuk melengkapi keberadaan Jogjaplan penting untuk didorong untuk memastikan jangkauan di akar rumput. Pelibatan melalui pembentukan kelompok masyarakat pengawal pembangunan dan anggaran di akar rumput pada level desa dapat membantu keberlanjutan serta dukungan terhadap proses pembangunan, karena muncul perasaan kepemilikan bersama terhadap program pembangunan. Program pembangunan yang dibuat tidak hanya melalui proses teknokratis pada level birokrasi pemerintahan, tetapi juga melibatkan masyarakat sampai level akar rumput juga dapat mencegah kemungkinan pembangunan yang justru mengorbankan kepentingan warga. Keberadaan platform daring seperti Jogjaplan pada dasarnya sebatas instrumen penghubung antara pemangku kepentingan dengan pengambil kebijakan. Namun, apabila ternyata tanpa diikuti dengan konsen untuk membentuk 
Jurnal Pemikiran Sosiologi Volume 5 No. 2, 2018

Jogjaplan dan Kelompok Warga Pengawal Anggaran dalam Perencanaan Pembangunan

di Daerah Istimewa Yogyakarta.

Anggalih Bayu Muh. Kamim, M. Rusmul Khandiq, Ichlasul Amal.

kelompok warga yang pro aktif dalam mengawal proses penganggaran dan perencanaan pembangunan hanya akan menjadi sebatas proses birokratis yang melupakan asas kepentingan publik. Pembentukan kelompok warga pengawal anggaran dan pembangunan menjadi agenda mendesak, agar masyarakat dapat terlibat langsung dalam proses perencanaan pembangunan dan penggunaan anggaran maupun platform alternatif seperti Jogjaplan. Oleh sebab itu, pembentukan, pendampingan dan pelibatan kelompok warga untuk terlibat langsung dalam proses perencanaan pembangunan dan penggunaan anggaran di DIY seharusnya menjadi inovasi utama yang harus dikerjakan.

\section{B. Metode Penelitian}

Kajian dilakukan dengan metode penelitian kualitatif deskriptif untuk melakukan evaluasi terhadap pemanfaatan Jogjaplan dan Jogjakendali dalam perencanaan anggaran di DIY selama ini, serta memberikan gambaran secara deskriptif perlunya kehadiran Kelompok Warga Pengawal Anggaran. Pengumpulan data dilakukan dengan teknik dokumentasi dengan melakukan penelusuran terhadap dokumen pemerintahan, laporan penelitian, artikel jurnal, dan sumber lain yang relevan dalam penelitian.
Penelusuran dilakukan terhadap laporan berbagai program NGO, regulasi, serta berbagai produk kebijakan yang telah ada. Pendalaman juga dilakukan dengan mengevaluasi secara langsung pemanfaatan platform jogjaplan.com. Analisis data dilakukan melalui tahap reduksi data, penyajian data serta verifikasi dan penarikan kesimpulan.

\section{Kerangka Teoritis}

Salah satu cara yang dapat digunakan untuk meningkatkan partisipasi masyarakat dalam proses pemerintahan adalah dengan menggunakan model participatory budgeting. Sebelumnya, di sini peneliti menggunakan pengertian participatory budgeting yang diajukan oleh Röcke (2014) sebagai pelibatan satuan masyarakat setara di tingkat kecamatan (municipal) secara langsung dalam proses penganggaran dan penentuan kebijakan. Perbedaan definisi muncul karena adanya istilah yang sama namun merujuk pada hal yang berbeda. Seperti yang dijelaskan oleh Brownell (dalam Ardin 2017) bahwa participatory budgeting (penganggaran partisipatif dalam bahasa Indonesia) lebih merujuk pada proses di mana individu-individu terlibat dalam penyusunan target anggaran dan berpengaruh dalam penyusunan tersebut di mana kinerja mereka 
Jurnal Pemikiran Sosiologi Volume 5 No. 2, 2018

Jogjaplan dan Kelompok Warga Pengawal Anggaran dalam Perencanaan Pembangunan

di Daerah Istimewa Yogyakarta.

Anggalih Bayu Muh. Kamim, M. Rusmul Khandiq, Ichlasul Amal.

akan dievaluasi dan kemungkinan akan dihargai berdasarkan pencapaian target anggaran yang mereka susun. Penggunaan istilah yang sama dengan definisi yang berbeda ini perlu dijelaskan terlebih dahulu. Sepanjang artikel ini, peneliti akan menggunakan definisi dari Röcke dengan merujuknya sebagai sebuah inovasi demokrasi.

Röcke (2014) menyebutkan, sebagai inovasi demokrasi, participatory budgeting dapat meningkatkan partisipasi masyarakat karena masyarakat lebih banyak dilibatkan dalam perumusan anggaran di mana sebelumnya elitokrasi atau kebergantungan terhadap golongan elite sebagai perumus anggaran menyebabkan banyak ketidakpercayaan karena sering tidak sesuainya hasil kebijakan dengan keinginan masyarakat. Adanya dorongan untuk menjadikan demokrasi deliberatif yang lebih banyak melibatkan masyarakat muncul sebagai cara untuk mengurangi kemungkinan-kemungkinan fraud dalam pemerintahan dan menghindari klientelisme yang muncul akibat dikuasainya penganggaran oleh partai-partai politik. Dari hasil penelitian Sintomer et.al (dalam Röcke 2014) juga didapati terdapat kaitan antara peningkatan jumlah partisipasi masyarakat dalam masalah kebijakan pemerintahan dan naiknya penerapan participatory budgeting di beberapa negara di Eropa. Menurut laporan dari Public Agenda bekerja sama dengan The Kettering Foundation (Lieighninger \& Rinehart 2016; Hagelskamp et.al 2016), participatory budgeting dapat meningkatkan partisipasi masyarakat terhadap pemerintah, meningkatkan legitimasi dari pemerintah daerah, dan memberikan edukasi kepada masyarakat mengenai penganggaran dan sistem kerja pemerintahan dengan lebih baik. Selain itu, participatory budgeting dapat meningkatkan deliberasi publik yang ditandai dengan semakin "pintarnya" pilihan publik, naiknya empati dan pemahaman terhadap orang dengan perbedaan pandangan dan kepada pemerintah, kebijakan yang lebih tepat sasaran, naiknya kesadaran terhadap kesenjangan yang ada, dan naiknya kapasitas penyelesaian masalah. Menurut Chohan, pelibatan masyarakat secara langsung dalam perumusan anggaran dapat meningkatkan kepercayaan masyarakat terhadap pemerintah sehingga berdampak baik bagi kestabilan ekonomi (theconversation.com, 27 April 2016). Dalam sudut pandang administratif pun, munculnya New Public Management pada 1990-an yang lebih melibatkan pengguna jasa manajemen (dalam hal ini, masyarakat) dengan anggapan bahwa pelayanan publik akan menjadi lebih efisien jika mereka mengembangkan pelayanan tersebut dengan menjalin hubungan yang 
Jurnal Pemikiran Sosiologi Volume 5 No. 2, 2018

Jogjaplan dan Kelompok Warga Pengawal Anggaran dalam Perencanaan Pembangunan

di Daerah Istimewa Yogyakarta.

Anggalih Bayu Muh. Kamim, M. Rusmul Khandiq, Ichlasul Amal.

dekat dengan pengguna jasa tersebut (Röcke 2014).

Ada setidaknya tiga tipe dalam participatory budgeting. Tiga tipe ini antara lain adalah demokrasi langsung (direct democracy), cogovernance, dan proses konsultatif-diskursif (consultative-discursive process). Ketiga tipe ini dapat disusun dalam sebuah kontinuum dengan titik ekstrem satu di demokrasi langsung dan titik ekstrem satunya di proses konsultatifdiskursif. Dalam model demokrasi langsung, ada dua bentuk pelibatan yaitu secara top-down melalui pemaparan langsung program kerja dari pemerintah daerah untuk kemudian mendapatkan legitimasi melalui voting atau ballot, dan secara bottom-up melalui rekomendasi- rekomendasi yang disampaikan oleh masyarakat secara langsung melalui kanalkanal yang disediakan oleh pemerintah. Sedangkan dalam model co-governance, masyarakat memiliki kekuatan secara legal untuk memengaruhi secara langsung beberapa kebijakan dan menjadi mitra dengan pemerintah dalam penyusunan anggaran. Kemudian dalam model konsultatif-diskursif, masyarakat dilibatkan dalam proses penyusunan anggaran sebagai konsultan yang ikut dalam diskusi mengenai anggaran melalui forum-forum publik seperti public hearing, focus group, dan round table. Keluaran dari forum tersebut terbatas pada rekomendasi pilihan yang diajukan kepada pemerintah. (Röcke 2014).

Dalam artikel ini, dengan melihat dari kasus Jogjaplan, peneliti lebih menggunakan model demokrasi langsung di mana dalam Jogjaplan sendiri belum adanya forum yang dapat menaungi dan menyosialisasikan program tersebut. Model participatory budgeting yang lebih memberikan masyarakat wadah sendiri berupa rembug warga untuk menentukan penganggaran yang diinginkan diharapkan dapat menjadi solusi dari terbatasnya penganggaran Jogjaplan pada pihak tertentu yang berujung pada elitokrasi.

Dalam model participatory budgeting, masyarakat dilibatkan secara langsung melalui forum-forum khusus di mana di dalam forum tersebut masyarakat dapat mengusulkan dan berunding mengenai apa saja kebijakan yang harus dilakukan oleh pemerintah. Model ini pertama kali muncul di Porto Alegre pada tahun 1980-an sebagai efek dari munculnya conselhos sebagai kerja sama

masyarakat-pemerintah, organisasi masyarakat (UAMPA) yang menghimpun suara masyarakat, serta amandemen konstitusi pada 1986-1988 pasca rezim militer berkuasa di Brazil pada 1964 - 1985 (Röcke 2014; Wampler 2007). Walaupun sebenarnya beberapa prototipe sudah muncul selama rezim militer seperti di Piracicaba 
Jurnal Pemikiran Sosiologi Volume 5 No. 2, 2018

Jogjaplan dan Kelompok Warga Pengawal Anggaran dalam Perencanaan Pembangunan

di Daerah Istimewa Yogyakarta.

Anggalih Bayu Muh. Kamim, M. Rusmul Khandiq, Ichlasul Amal.

pada 1977-1982 yang mencoba untuk mengutamakan partisipasi langsung dari masyarakat dalam penentuan kebijakan lokal (Souza 2001). Hingga sekarang, participatory budgeting sudah dilakukan di berbagai belahan dunia seperti di Amerika Utara (Participatory Budgeting Project 2017), Skotlandia (local.gov.uk, 12 Desember 2016), dan Ghana (Asare 2012). Sebenarnya, di Indonesia sendiri, participatory budgeting sudah mulai diterapkan di beberapa daerah. Dalam PP No. 8 Tahun 2008, proses perencanaan pembangunan harus melibatkan pemangku kepentingan yang secara langsung maupun tidak langsung akan terdampak kebijakan tersebut. Beberapa contoh participatory budgeting di Indonesia terjadi di Surakarta melalui kelompok terbatas dan Jepara melalui LSM (Widodo, 2016).

Participatory budgeting (PB) adalah proses dimana warga mengajukan aspirasi dan prioritas mereka untuk perbaikan sipil, pengaruh melalui diskusi, dan negosiasi alokasi anggaran. Porto Alegre salah satu kota terpadat di Brasil Selatan menerapkan penganggaran partisipatif sejah tahun 1989.

Penganggaran partisipatif telah menghasilkan peningkatan fasilitas bagi masyarakat Porto Alegre. Misalnya, saluran pembuangan dan sambungan air naik dari 75 persen total rumah tangga pada 1988 menjadi 98 persen pada tahun 1997. Jumlah peserta dalam proses penganggaran partisipatif di Porto Alegre mencapai 40.000 per tahun dalam waktu kurang dari satu dekade, menunjukkan kemampuan penganggaran partisipatif untuk mendorong meningkatkan keterlibatan warga negara. Keberhasilan partisipasi orang-orang dalam menentukan penggunaan dana kesejahteraan masyarakat di kota Porto Alegre telah menginspirasi banyak kota lain untuk mengikutinya. Sejauh ini, dari 5.571 kotamadya di Brasil, lebih dari 140 (sekitar 2,5 persen) telah mengadopsi penganggaran partisipatif (Goldfrank 2012).

Dalam bukunya Wampler (2007) mengungkapkan indikator keberhasilan dari penganggaran partisipatif adalah peningkatan tingkat partisipasi. Jumlah peserta di Porto Alegre tumbuh dari kurang 1.000 per tahun pada tahun 1990 menjadi lebih dari 16.000 pada tahun 1998, menjadi sekitar 40.000 pada tahun 1999. Partisipasi tidak hanya terbatas pada kelas menengah atau pendukung konvensional Partai Pekerja. Orang-orang dari kelompok berpenghasilan rendah juga mengambil bagian aktif dalam prosesnya.

Proses penganggaran partisipatif yang melibatkan warganya dalam menentukan skala prioritas berdampak pada kebutuhan layanan dasar yang meningkat. Wampler (2007) lebih lanjut menyatakan setelah 
Jurnal Pemikiran Sosiologi Volume 5 No. 2, 2018

Jogjaplan dan Kelompok Warga Pengawal Anggaran dalam Perencanaan Pembangunan

di Daerah Istimewa Yogyakarta.

Anggalih Bayu Muh. Kamim, M. Rusmul Khandiq, Ichlasul Amal.

adanya penganggaran partisipatif unit perumahan umum baru, yang hanya menampung 1.700 penduduk baru pada tahun 1986, menampung tambahan 27.000 pada tahun 1989. Saluran pembuangan dan sambungan air di kota Porto Alegre naik dari 75 persen dari total rumah tangga pada 1988 menjadi 98 persen pada tahun 1997. Jumlah sekolah bertambah empat kali lipat sejak 1986. Anggaran kesehatan dan pendidikan Porto Alegre meningkat dari 13 persen pada tahun 1985 menjadi hampir 40 persen pada tahun 1996. Sebagai tantangannya Goldfrank (2012) menyebutkan bahwa penganggaran partisipatif di Porto Alegre masih mengalami kurangnya representasi orang yang sangat miskin dalam prosesnya. Selain itu, keterbatasan sumber daya keuangan karena partisipasi masih dengan metode konvensional, belum menggunakan teknologi.

Menurut Sintomer (dalam Röcke, 2014), di negara-negara Eropa sendiri ada beberapa masalah struktural yang menyebabkan berkurangnya partisipasi masyarakat dan berdampak pada meningkatnya tren participatory budgeting. Hal itu antara lain ketidakmampuan pemerintah untuk menghadapi krisis sosio-ekonomi yang berdampak pada naiknya kesenjangan di beberapa negara, rusaknya politik kelas akibat ketidakpercayaan masyarakat terhadap asosiasi berbasis kelas (seperti serikat pekerja), lalu meningkatnya ketidakmampuan pemerintah untuk menghadapi masalah dan ketidakamanan di masa depan, kemudian krisis birokrasi pasca reformasi struktur birokrasi tradisional melalui New Public Management yang menekankan partisipasi masyarakat yang lebih luas, kemudian hadangan ideologi yang muncul akibat hilangnya ideologi yang dapat menarik banyak massa seperti sosialisme, dan masalah internal dari sebuah sistem politik yang terlampau homogen karena dikuasai oleh klientelisme.

\section{Evaluasi Pemanfaatan Jogjaplan dalam Perencanaan Anggaran dan Pembangunan DIY}

Jogjaplan pada dasarnya dibentuk sebagai upaya reformasi birokrasi sekaligus integrasi proses perencanaan pembangunan daerah secara daring. Jogjaplan dibentuk dengan landasan Undang Undang Nomor 25 Tahun 2004 tentang Sistem Perencanaan Pembangunan Nasional; Undang Undang Nomor 32 Tahun 2004 tentang Pemerintahan Daerah; Peraturan Pemerintah Nomor 08 Tahun 2008 tentang Tahapan, Tata Cara Penyusunan, Pengendalian dan Evaluasi Pelaksanaan, Perencanaan Pembangunan Daerah; Permendagri Nomor 54 Tahun 2010 tentang Pelaksanaan Peraturan Pemerinta Nomor 08 Tahun 2008; Undang Undang Nomor 11 Tahun 2008 Informasi dan 
Jurnal Pemikiran Sosiologi Volume 5 No. 2, 2018

Jogjaplan dan Kelompok Warga Pengawal Anggaran dalam Perencanaan Pembangunan

di Daerah Istimewa Yogyakarta.

Anggalih Bayu Muh. Kamim, M. Rusmul Khandiq, Ichlasul Amal.

Transaksi Elektronik; Undang Undang Nomor 23 Tahun 2014 tentang Pemerintahan Daerah (bappeda.jogjaprov.go.id, 5 April 2016).

Jogjaplan diklaim memiliki beberapa manfaat bagi perencanaan pembangunan daerah. Pertama, Input data, proses, alur dan laporan sesuai dengan Permendagri No 54 Tahun 2010, dan Urusan sesuai dengan Undang Undang Nomor 23 Tahun 2014. Kedua, Menjaga konsistensi RKPD - KUA/PPAS RKPD Perubahan - KUA/PPAS Perubahan sehingga sesuai dengan RPJMD dan memproteksi SKPD agar hanya bisa mengambil program kegiatan yang menjadi urusannya saja. Ketiga, Penyusunan laporan secara manual yang sebelumnya memakan waktu berminggu-minggu bisa selesai dalam waktu hitungan detik. Bappeda memiliki kemampuan untuk mengkoreksi dan memodifikasi rencana program/kegiatan yang telah diinput oleh SKPD (bappeda.jogjaprov.go.id, 5 April 2016).

Bappeda juga dapat membuat batasan pagu indikatif untuk setiap SKPD sesuai dengan pertimbangan ketersediaan anggaran, kepentingan dan prioritas daerah. Berikutnya, terdapat menu analisis bagi pemangku kepentingan agar dapat memahami dengan cepat kesesuaian antara rencana yang telah disusun terhadap visi misi, prioritas, sasaran dan lokasi. Serta, dapat diakses oleh masyarakat sebagai wujud keterbukaan informasi pemerintah. Dapat menampung usulan masyarakat sebagai wujud mekanisme bottom up yang komunikatif. Memiliki fitur GIS dan entri data spasial guna membangun konsep perencanaan berbasiskan kewilayahan (bappeda.jogjaprov.go.id, 5 April 2016).

Jogjaplan juga telah membawa DIY pada berbagai penghargaan. Telah berhasil membawa DIY sebagai juara Pangripta tahun 2014, 2015 dan 2016 sebagai wujud perencanaan daerah yang baik. Dan, Membawa DIY menjadi 5 besar kompetisi Inovasi Pelayanan Publik yang diadakan oleh Kementerian Pendayagunaan Aparatur Negara dan Reformasi Birokrasi Tahun 2016 (bappeda.jogjaprov.go.id, 5 April 2016).

Untuk tahun 2015, Jogjaplan juga memenangkan Kompetisi Inovasi Pelayanan Publik yang memberikan anugerah kepada melalui 25 penghargaan inovasi yang dibagi menjadi tiga kategori yaitu tiga inovasi kementerian, lima inovasi provinsi, sepuluh inovasi kabupaten, dan tujuh inovasi kota. Tercatat beberapa inovasi yang layak dikedepankan, bersama platform daring lain seperti Layanan Tujuh Menit (LANTUM) oleh Kementerian Agraria dan Tata Ruang/BPN; Paket Kebijakan Investasi (PaKSi) oleh Pemkab Pinrang; dan Klinik Lansia Puskesmas 
Jurnal Pemikiran Sosiologi Volume 5 No. 2, 2018

Jogjaplan dan Kelompok Warga Pengawal Anggaran dalam Perencanaan Pembangunan

di Daerah Istimewa Yogyakarta.

Anggalih Bayu Muh. Kamim, M. Rusmul Khandiq, Ichlasul Amal.

Putri Ayu oleh Pemkot Jambi (Badan

Pengawasan Keuangan dan Pembangunan [BPKP] 2015).

Bappeda DIY membangun sistem informasi perencanaan yang menampilkan perencanaan secara detail dan interaktif berbasis web base (internet), yang dapat dikunjungi setiap saat pada www.jogjaplan.com. Pengunjung dapat menelusuri secara detail perencanaan yang sedang disusun SKPD, ataupun melihat ringkasan eksekeutif secara makro atas keseluruhan perencanaan yang dilaksanakan secara real time. Masyarakat DIY dapat berperan memberikan usulan dan pendapat secara tertulis terhadap program kegiatan yang sedang direncanakan di dalam forum Usulan Masyarakat, dengan mengupload proposal dan/atau gambar yang mendukung usulan tersebut (Kementerian Pendayagunaan Aparatur Negara dan Reformasi 2015).

Jogjaplan menjadi alat monitoring terhadap proses perencanaan di mana halaman eksekutif secara cepat dan akurat menampilkan informasi mengenai four track strategy dan pe- nentuan affirmative policy. Ketika terjadi ketidaktepatan dalam perencanaan beserta alokasi pendanaan dapat dideteksi lebih dini serta dilakukan perbaikan. Uji coba pertama kali tahun 2011 dan dilaksanakan tahun 2012 untuk perencanaan 2013 (Kementerian
Pendayagunaan Aparatur Negara dan Reformasi 2015) Strategi pelaksanaan Jogjaplan terdiri atas:

1. Pengelolaan aplikasi yang berkelanjutan

2. Quality control sistem

3. Penguatan keterampilan staf Bappeda

4. Komitmen pimpinan

5. Akuntabel dan Berkelanjutan

6. Penguatan kapasitas pengguna aplikasi

7. Dukungan operasional

Pemangku kepentingan terdiri dari Pemkab khususnya Bappeda, dunia usaha, dan masyarakat. Sumber daya Keuangan berasal dari APBD Kota Yogyakarta. Jogjaplan berhasil mewujudkan kemudahan dalam penyusunan dokumen; kemudahan dalam menyajikan informasi; kemudahan dalam pelaksanaan pekerjaan; peningkatan produktivitas kerja; transparansi dan akuntabilitas, dan memperluas jaringan prtisipasi masyarakat. Dampak Jogjaplan antara lain, trilateral desk (share kegiatan DIY dengan Kabupaten/Kota), komitmen anggaran, kejelasan mekanisme kerja, jaringan internet, ketepatan waktu pembuatan, rangkuman eksekutif, affirmative policy, tindakalanjut aspirasi masyarakat, transparansi dan akuntabilitas, dan dokumen perencanaan berbasis teknologi informasi 
Jurnal Pemikiran Sosiologi Volume 5 No. 2, 2018

Jogjaplan dan Kelompok Warga Pengawal Anggaran dalam Perencanaan Pembangunan

di Daerah Istimewa Yogyakarta.

Anggalih Bayu Muh. Kamim, M. Rusmul Khandiq, Ichlasul Amal.

(Kementerian Pendayagunaan Aparatur

Negara dan Reformasi 2015).

Menurut Astiti (2015) aplikasi berbasis teknologi informasi dalam participatory budgetting dalam Jogjaplan memiliki fitur antara lain sebagai berikut:

a. Aplikasi yang memunyai kemampuan untuk pembuatan berbagai laporan yang menyita waktu dengan proses waktu pencetakan dalam menit/detik;

b. Aplikasi yang mempunyai kemampuan untuk menjaga kesesuaian RPJMD, RKPD, KUA/PPAS. RKPD sebagai penjabaran perencanaan tahunan dari RPJMD dan hasil penjaringan aspirasi masyarakat melalui musrenbang, merupakan pedoman penyusunan PPAS. PPAS berfungsi sebagai dokumen untuk pembicaraan pendahuluan APBD yang menjembatani antara perencanaan (RKPD) dengan kebijakan dan rancangan anggaran berdasar pada ketersediaan atau pagu anggaran. PPAS yang telah disepakati dijadikan pedoman untuk menyusun RAPBD yang kemudian disahkan menjadi APBD selama ini masih terjadi perbedaan yang mencolok mulai dari dokumen RKPD sampai dengan APBD maupun pelaksanaannya c. Aplikasi yang memiliki kemampuan untuk mengoreksi dan memodifikasi rencana program/kegiatan yang sudah diinput oleh SKPD, nomor rekening, nomenklatur nama program dan kegiatan dijamin tepat karena sudah sesuai dengan peraturan perundangan yang berlaku dan bisa ditambahkan guna mengakomodir kebutuhan daerah.

d. Aplikasi dapat membuat batasan pagu indikatif untuk setiap SKPD sesuai dengan pertimbangan kemampuan fiskal.

e. Aplikasi mempunyai kemampuan mencetak langsung dan fitur untuk ekspor dokumen ke dalam format excel.

f. Aplikasi Jogjaplan mempunyai menu analisis bagi pemangku kepentingan agar dapat dengan cepat memahami kesesuaian rencana yang telah disusun terhadap visi, misi, prioritas, sasarandan lokasi.

g. Aplikasi Jogjaplan siap diintegrasikan dengan sistem informasi lainnya yang saling mendukung, seperti sistem informasi keuangan daerah (SIKPD), sistem informasi monev, dan sistem informasi UKPPD (Bappenas).

h. Aplikasi Jogjaplan siap mewujudkan perencanaan pembangunan secara 
Jurnal Pemikiran Sosiologi Volume 5 No. 2, 2018

Jogjaplan dan Kelompok Warga Pengawal Anggaran dalam Perencanaan Pembangunan

di Daerah Istimewa Yogyakarta.

Anggalih Bayu Muh. Kamim, M. Rusmul Khandiq, Ichlasul Amal.

transparan, responsive, efisien,

akuntabel, partisipatif dan terukur.

Aplikasi Jogjaplan yang dikembangkan oleh Badan Perencanaan Pembangunan Daerah Provinsi DIY memberikan dampak yang positif dalam rangka proses penyusunan perencanaan pembangunan di DIY. Berbagai fitur yang ditawarkan dari aplikasi ini, memberi manfaat bagi Bappeda Prov DIY dalam menyusun dokumen Perencanaan secara transparan, responsive, efisien, akuntabel, partisipatif dan terukur (Astiti 2015). Kelebihan lain dari aplikasi Jogjaplan ini, menawarkan input yang mudah, sederhana dan tidak memakan waktu yang lama sehingga mampu menyajikan berbagai kebutuhan informasi yang diperlukan setiap saat, seperti: statistik per SKPD, statistik per bidang urusan, Laporan rencana program dan kegiatan, laporan kebutuhan renja, dst. Selain itu, aplikasi ini dibuat berbasis web, sehingga bisa diakses dari mana saja menggunakan koneksi internet dengan berbagai macam device, seperti: telepon selular, komputer, laptop dan tablet. Aplikasi Jogjaplan juga dibangun untuk mencegah human error, seperti: mencegah SKPD mengambil Program/Kegiatan yang bukan menjadi bidang urusannya, tidak terjadi lagi kesalahan penjumlahan dan pengurutan, menjaga kesesuaian RKPD sampai dengan proses terwujudnya KUA-PPAS. SKPD tidak dapat membuat program/kegiatan yang belum tercantum di RPJMD, tidak ada lagi kekeliruan nomor rekening dan nomenklatur. Dengan aplikasi ini tugas Bappeda menjadi lebih mudah dan ringan dimana dulu pengecekan dilakukan satu persatu secara manual, namun sekarang dilakukan secara otomatis oleh komputer, berbagai macam jenis laporan juga dapat dihasilkan dari aplikasi ini. Ditambah pula menu eksekutif untuk memfasilitasi para pemangku kepentingan dan masyarakat dalam berpatisipasi pada proses perencanaan pembangunan di Provinsi DIY (ibid).

Penerapan website jogjaplan.com pada BAPPEDA Daerah Istimewa Yogyakarta, adalah efektif karena memberikan manfaat bagi masyarakat maupun BAPPEDA DIY itu sendiri, meningkatkan efisiensi dalam kinerja pegawai, meningkatkan transparansi dan partisipasi publik. Pengukuran efektivitas penerapan website jogjaplan.com pada BAPPEDA Daerah Istimewa Yogyakarta, dilakukan dengan menggunakan indikator dimensi manfaat, dimensi efisiensi, dimensi partisipasi, dimensi transparansi dan dimensi manajemen perubahan (Miyanto dan Rahayu 2017). Dalam penerapan website jogjaplan.com, BAPPEDA DIY selalu melakukan perbaikan, pengembangan dan studi banding agar website tersebut dapat dijalankan dengan baik. Selain, melakukan hal tersebut dengan adanya SDM yang cukup dan 
Jurnal Pemikiran Sosiologi Volume 5 No. 2, 2018

Jogjaplan dan Kelompok Warga Pengawal Anggaran dalam Perencanaan Pembangunan

di Daerah Istimewa Yogyakarta.

Anggalih Bayu Muh. Kamim, M. Rusmul Khandiq, Ichlasul Amal.

mumpuni menjadi salah satu faktor lain yang membuat BAPPEDA DIY dapat menjalankan website jogjaplan.com dengan baik. Namun, BAPPEDA DIY belum pernah melakukan evaluasi secara resmi dari penerapan website jogjaplan.com, evaluasi secara resmi perlu dilakukan, agar BAPPEDA DIY dapat mengetahui apakah jogjaplan sudah berjalan dengan baik atau belum. Namun, penggunaan Jogjaplan memiliki kelemahan, karena prosesnya yang masih terkesan teknokratis. Adapun faktor yang menghambat penerapan dari website jogjapan.com, antara lain ketersediaan bandwidth setiap SKPD yang berbeda-beda, adanya human error seperti salah ketik, website jogjaplan.com masih sangat bergantung pada jaringan internet. Selain, faktor penghambat ada pula faktor yang mendukung penerapan dari website jogjapan.com, antara lain adanya komitmen pegawai dari level bawah sampai level pimpinan atau top manager, SDM yang bekerja dengan baik, adanya respon positif dari masyarakat terhadap website jogjaplan.com (ibid).

Pemanfaatan e-government seperti Jogjaplan pada dasarnya digunakan untuk melakukan reformasi birokrasi dan tata kelola pemerintahan. Secara khusus, dalam upaya meningkatkan tata kelola pemerintahan, partisipasi masyarakat akan diwadahi melalui pengembangan aplikasi dan ruang keterlibatan publik dalam sistem perencanaan dan pengendalian pembangunan. Masyarakat diklaim dapat menyampaikan usulan kegiatan kepada setiap SKPD dalam rangka perencanaan pembangunan melalui Jogjaplan.com dan dapat pula mengakses informasi untuk pengendalian pelaksanaan pembangunan dengan masuk ke tautan

monevapbd.jogjaprov.go.id.

Dengan menggunakan username dan password 'publik', masyarakat diklaim bisa mendapatkan informasi memadai tentang bagaimana pelaksanaan dan kinerja pembangunan di DIY untuk kurun waktu tertentu (Pemerintah DIY, 2015).

Klaim bahwa masyarakat kemungkinan dapat berpartisipasi baik dalam mengakses Jogjaplan ternyata masih patut dipertanyakan mengingat masih rendahnya Indeks Pembangunan Teknologi Komunikasi dan Informasi. Data dari Badan Pusat Statistik pada tahun 2016 menunjukan Daerah Istimewa Yogyakarta memiliki indeks sebesar 6,12 (sumber: https://tirto.id. Diakses 15 Desember 2015). Hal ini justru mengalami kemunduran dibandingkan tahun 2015, DIY meraih indeks sebesar 6,45 (sumber: https://lokadata.beritagar.id, Diakses 15 Desember 2015). Indeks tersebut lantas dijadikan BPS sebagai suatu ukuran standar yang dapat menggambarkan tingkat pembangunan teknologi informasi dan 
Jurnal Pemikiran Sosiologi Volume 5 No. 2, 2018

Jogjaplan dan Kelompok Warga Pengawal Anggaran dalam Perencanaan Pembangunan

di Daerah Istimewa Yogyakarta.

Anggalih Bayu Muh. Kamim, M. Rusmul Khandiq, Ichlasul Amal.

komunikasi suatu wilayah, kesenjangan digital, serta potensi pengembangan TIK. Semakin rendah nilai pada indeks itu artinya pembangunan TIK di suatu wilayah masih belum optimum, begitu juga sebaliknya.

Beberapa daerah lebih progresif dalam menggunakan teknologi informasi dalam kebijakan perencanaan pembangunan dan pengukuran kinerja, termasuk DI Yogyakarta dan Provinsi DKI Jakarta. Provinsi DI Yogyakarta mulai menerapkannya pada tahun 2011 dan banyak pihak menyambut ini. Awalnya, sistem itu diterapkan untuk meningkatkan program pemulihan setelahnya gempa bumi besar yang melanda wilayah itu pada 2006 (Junanto 2017). Dalam konteks birokratis, pemanfaatan platform daring seperti Jogjaplan sendiri memiliki banyak masalah. Umumnya, masalah sumber daya manusia muncul dalam kebijakan perencanaan pembangunan, manajemen keuangan, dan manajemen sumber daya manusia. Menurut kasus lain yang terkait dengan praktik manajemen keuangan, ternyata masalah sumber daya manusia tidak hanya terjadi di tingkat pemerintah daerah, tetapi juga di lembaga pemerintah pusat. Masalah-masalah itu biasa terjadi di wilayah lain. Adanya unit pelaporan kinerja pemerintah daerah tentang manajemen keuangan juga bermasalah, karena laporan kinerja keuangan biasanya disiapkan oleh unit perencanaan. Tentu saja ada unit keuangan di setiap organisasi, tetapi fungsinya hanya sebagai bendahara bukan penyampai akuntabilitas kinerja (ibid). Faktor pendukung dari kerangka rasional /teknokratis adalah informasi dan sistem pengukuran kinerja yang ada di pemerintahan. Dalam diskusi tentang aspek ini, kita melihat kondisi yang mendukung atau tidak terhadap adopsi dan implementasi pemanfaatan informasi kinerja dalam perencanaan pembangunan, praktik manajemen keuangan, dan manajemen sumber daya manusia. Pada prinsipnya, informasi kinerja dapat dilihat dari dua sisi: ketersediaan (pasokan) dan kebutuhan (permintaan). Pasokan berarti bagaimana informasi kinerja diperoleh dan dilaporkan (ibid). Permintaan berarti kebutuhan informasi kinerja. Namun, bagian ini berfokus pada sisi penawaran alihalih sisi permintaan, karena dianggap sebagai persyaratan eksternal. Dari sisi suplai informasi kinerja, masing-masing instansi pemerintah di keduanya tingkat pusat dan daerah diperlukan untuk menyiapkan laporan kinerja terkait program pengembangan dan eksekusi finansial. Dari sisi permintaan, laporan kinerja diminta oleh lembaga pusat dengan wewenang untuk mengevaluasi kinerja. Instansi pusat mempengaruhi kompleksitas manajemen kinerja. Akibatnya, otoritas di antara para pemangku kepentingan ini 
Jurnal Pemikiran Sosiologi Volume 5 No. 2, 2018

Jogjaplan dan Kelompok Warga Pengawal Anggaran dalam Perencanaan Pembangunan

di Daerah Istimewa Yogyakarta.

Anggalih Bayu Muh. Kamim, M. Rusmul Khandiq, Ichlasul Amal.

memotong atau bahkan tumpang tindih, dengan yang lain (ibid).

Informasi kinerja tentang perencanaan pembangunan terkait erat dengan praktek manajemen keuangan. Laporan, seperti LAKIP, terdiri dari kinerja keuangan lembaga pemerintah. Laporan keuangan juga meninjau implementasi program yang berasal dari kebijakan perencanaan. Karena itu, tidak ada yang jelas batas antara perencanaan dan pencapaian kinerja keuangan dalam laporan kinerja.Namun, masalah utama yang terjadi dalam laporan realisasi perencanaan terkait fokus pengukuran dan pelaporan. Untuk menanggapi permintaan dari pemerintah pusat, laporan kinerja dari pemerintah daerah dapat diimprovisasi hanya untuk memenuhi kewajiban pelaporan pada akhirnya.Selain itu, ada banyak jenis laporan yang harus disiapkan, terutama oleh pemerintah lokal. Argumen yang sering dinyatakan sebagai alasan dari berbagai jenis laporan kinerja adalah karena tujuan dan fokus yang berbeda dari masing-masing evaluasi (ibid).

Persoalan partisipasi masyarakat dalam perencanaan pembangunan dan anggaran melalui Jogjaplan juga masih minim. Hal ini ditunjukan dengan minimnya pengakses Jogjaplan. Minimnya pengakses jogjaplan.com ditengarai karena kurangnya sosialisasi. Padahal, melalui laman ini, usulan warga langsung diterima Bappeda dan diteruskan ke instansi terkait. Usulan yang masuk akan diklarifikasi dan disusun menjadi program keistimewaan di tahun berikutnya. Inovasi Bappeda untuk menjaring usulan warga via online seharusnya diikuti sosialisasi dan edukasi. Tanpa itu, website hanya bisa diakses kalangan terbatas. Terbukti, sudah tiga tahun dikembangkan sampai dengan tahun 2014, tapi jumlah usulan program yang diterima Pemda masih nol.

Partisipasi masyarakat D.I. Yogyakarta dalam penggunaan Jogjaplan untuk mengusulkan rancangan pembangunan berupa RKPD maupun KUA PPAS melalui proposal juga masih terbilang rendah. Dalam platform jogjaplan.com sendiri sepanjang tahun 2015 dan 2016, tim peneliti tidak menemukan adanya data yang menunjukan intensitas usulan masyarakat dalam menggunakan Jogjaplan untuk terlibat dalam perencanaan pembangunan dan anggaran. Baru pada tahun anggaran 2017, peneliti menemukan adanya data 12 usulan dari masyarakat melalui Jogjaplan, tetapi sayangnya tidak direspon dengan baik oleh Pemerintah D.I. Yogyakarta dengan persetujuan terhadap usulan masyarakat sama sekali tidak ada. Pada tahun anggaran 2018, peneliti menemukan data adanya tiga usulan yang masuk dari masyarakat melalui Jogjaplan, itupun belum disetujui oleh pihak Pemda DIY. Rendahnya 
Jurnal Pemikiran Sosiologi Volume 5 No. 2, 2018

Jogjaplan dan Kelompok Warga Pengawal Anggaran dalam Perencanaan Pembangunan

di Daerah Istimewa Yogyakarta.

Anggalih Bayu Muh. Kamim, M. Rusmul Khandiq, Ichlasul Amal.

partisipasi masyarakat dan responsivitas

Pemda DIY dalam menggunakan Jogjaplan menunjukan belum munculnya secara riil partisipasi masyarakat dalam perencanaan pembangunan dan anggaran. Dalih penggunaan partisipasi masyarakat yang diklaim sudah muncul melalui musrenbang dan disinkronisasi melalui Jogjaplan juga sepertinya tidak mewadahi secara riil keterlibatan warga dalam perencanaan pembangunan dan anggaran. Penggunaan musrenbang yang terkesan dalam waktu singkat tanpa pelibatan masyarakat secara berkelanjutan sebenarnya telah menunjukan kelemahan yang sudah banyak disorot, sehingga tidak menutupi kekurangan dari penggunaan Jogjaplan.

Proses perencanaan pembangunan daerah telah diklaim memiliki jaminan mengakomodasi kepentingan umum oleh negara dengan adanya Musyawarah Perencanaan Pembangunan (Musrenbang). Akan tetapi, efektivitas pelaksanaan Musrenbang dalam merumuskan agenda publik dalam kebijakan perencanaan pembangunan daerah dipertanyakan, apakah aspirasi masyarakat akan benar-benar diakomodasi oleh pemerintah. Menurut Wahyunadi Ashari dan Hailuddin (2015) penyerapan aspirasi publik dalam perumusan kebijakan publik sendiri dipengaruhi oleh beberapa faktor yakni:
1. Ketersediaan anggaran.

2. Kepentingan politik terhadap penyerapan partisipasi masyarakat dalam APBD.

3. Kualitas usulan masyarakat terhadap penyerapan partisipasi masyarakat.

4. Tingkat kepentingan terhadap penyerapan partisipasi masyarakat dalam APBD.

Proses identifikasi masalah dari hasil Musrenbang juga tidak semua aspirasi publik dapat diakomodasi, karena harus menyesuaikan dengan kemampuan anggaran daerah, sehingga harus mendorong pemerintah daerah mencari mitra untuk turut mensukseskan pembangunan daerah (Abady 2013).

Sedikitnya jumlah pengakses Jogjaplan juga dapat dilihat, karena rendahnya literasi digital kalangan usia dewasa (20 tahun ke atas) di DIY. Hal ini terlihat dari mayoritas dari usaha gerakan literasi digital di DIY yang justru lebih banyak bermitra dengan pihak sekolah, dibandingkan berinteraksi dengan kalangan usia dewasa terutama di pedesaan. Hasil riset dari tim JAPELIDI pada tahun 2017 menunjukan kegiatan yang bermitra dengan sekolah mencapai 29 kegiatan, sementara dengan pemerintah mencapai 8 kegiatan. Berdasarkan kategorisasi pelakunya, maka terlihat bahwa pelaku literasi digital dari 
Jurnal Pemikiran Sosiologi Volume 5 No. 2, 2018

Jogjaplan dan Kelompok Warga Pengawal Anggaran dalam Perencanaan Pembangunan

di Daerah Istimewa Yogyakarta.

Anggalih Bayu Muh. Kamim, M. Rusmul Khandiq, Ichlasul Amal.

kalangan kampus paling banyak ditemukan di Yogyakarta (57 kegiatan). Sementara itu, jika dilihat dari clusternya, Kategori peneliti, komunitas dan masyarakat umum sebagai target sasaran paling banyak dijumpai di Yogyakarta. Gerakan literasi digital di Yogyakarta yang masih berfokus di perkotaan dan kalangan anak muda tampaknya telah mempengaruhi literasi digital masyarakat dalam mengakses e-governance seperti Jogjaplan (Kurnia dan Astuti 2017). Penerapan Jogjaplan juga dapat disandingkan dengan aplikasi e-musrenbang di Surabaya yang cenderung lebih baik dalam mewadahi partisipasi warga. E-musrenbang adalah aplikasi yang digunakan untuk membantu kegiatan musyawarah perencanaan pembangunan (musrenbang) Kota Surabaya secara online. Pelaksanaan Musrenbang merupakan salah satu tahapan dalam proses penyusunan perencanaan pembangunan. Tujuan utamanya adalah menampung aspirasi seluruh lapisan masyarakat (Kasim, Azhar, dkk 2015). Pada proses Musrenbang ini, masyarakat Surabaya dapat menyampaikan usulan-usulan dan kritikan mengenai pembangunan kota melalui ketua RW setempat. Ketua RW akan menyampaikan usulan-usulan tersebut dengan melakukan login ke aplikasi e-musrenbang. Selanjutnyna, usulan-usulan tersebut diverifikasi oleh Lurah, Camat, SKPD, dan Bappeko.
Berdasarkan pada penelitian dan hasil publikasi mengenai efektifitas e- musrenbang di Kota Surabaya dalam sistem perencanaan pembangunan berparadigma masyarakat oleh Yunas (2017) bahwa Kota Surabaya selama kurang lebih 5 tahun sejak 2010 telah berhasil menerapkan sistem berbasis teknologi, informasi dan komunikasi tersebut dan dinilai mampu memperluas akses masyarakat dalam memberikan usulan pada proses perencanaan pembangunan. Selain itu, e-musrenbang juga dinilai mampu memotong proses- proses panjang penjaringan usulan pembangunan di masyarakat agar usulan yang masuk lebih tepat, terarah dan akurat. Tentunya keberadaan emusrenbang ini, penerapannya tidak hanya sesuai dengan UU No. 25 tahun 2004 tentang Sistem Perencanaan Pembangunan melainkan Inpres No. 3 tahun 2003 tentang Kebijakan Strategi Nasional E-Government. Pun sistem emusrenbang ini mampu dijadikan sebuah pelajaran penting

bagi perencanaan pembangunan berparadigma masyarakat, dimana masyarakat tidak hanya dijadikan objek melainkan subjek pembangunan. 
Jurnal Pemikiran Sosiologi Volume 5 No. 2, 2018

Jogjaplan dan Kelompok Warga Pengawal Anggaran dalam Perencanaan Pembangunan

di Daerah Istimewa Yogyakarta.

Anggalih Bayu Muh. Kamim, M. Rusmul Khandiq, Ichlasul Amal.

\section{E. Kelompok Warga Pengawal Anggaran dan Partisipasi Masyarakat dalam Perencanaan Anggaran dan Pembangunan DIY}

Model peran serta masyarakat dalam proses Perencanaan dan Penganggaran Daerah disebut sebagai Forum Warga. Peran Forum Warga dalam mewujudkan prinsip-prinsip Pemerintahan Yang Baik dan Bersih secara ideal dapat diidentifikasikan sebagai berikut:

1. Forum Warga menunjang prinsip transparansi, akuntabilitas dan demokratisasi

2. Forum Warga sebagai Sarana untuk membangun komunikasi dan demokratisasi lokal agar dapat terwujud lebih cepat

3. Forum Warga sebagai perwujudan pemenuhan hak masyarakat atas informasi \& partisipasi dalam pelayanan publik pada pemerintahan

4. Forum Warga sebagai sarana kontrol masyarakat setelah adanya otonomi pemerintah daerah \& pemilihan pimpinan daerah secara langsung

5. Forum Warga yang bertujuan mengurangi praktik korupsi karena adanya transparansi \& partisipasi

Selain forum warga, penggunaan Jogjaplan sebagai clearing house yang memberikan informasi tentang program/proyek/kegiatan yang akan dilaksanakan pada tahun anggaran tertentu, khususnya pada masyarakat yang menjadi sasaran program/proyek/kegiatan tetap digunakan. Masyarakat penerima manfaat ini diharapkan peran aktifnya untuk menginformasikan ke forum warga atau langsung kepada DPRD bila terjadi hal-hal yang menyimpang atau bila tidak puas dengan suatu kegiatan/proyek/program tertentu melalui sarana komunikasi yang ada misalnya surat, telepon, e-mail dan sebagainya. Informasi ini akan menjadi masukan bagi

DPRD dalam menilai laporan pertanggungjawaban kepala daerah. Proses yang juga harus diawasi adalah proses tender karena selama ini tender dipahami sebagai proses yang penuh dengan nuansa yang cenderung korup dan nepotis. Perlu juga dibuat mekanisme yang fair, transparan, dan adil sehingga tingkat kebocoran anggaran dapat diturunkan. Partisipasi Masyarakat dalam tahap pelaporan dan evaluasi, tahapan ini berupa laporan pertanggungjawaban tahun anggaran oleh kepala daerah kepada DPRD (Sopanah, 2009). 
Jurnal Pemikiran Sosiologi Volume 5 No. 2, 2018

Jogjaplan dan Kelompok Warga Pengawal Anggaran dalam Perencanaan Pembangunan

di Daerah Istimewa Yogyakarta

Anggalih Bayu Muh. Kamim, M. Rusmul Khandiq, Ichlasul Amal

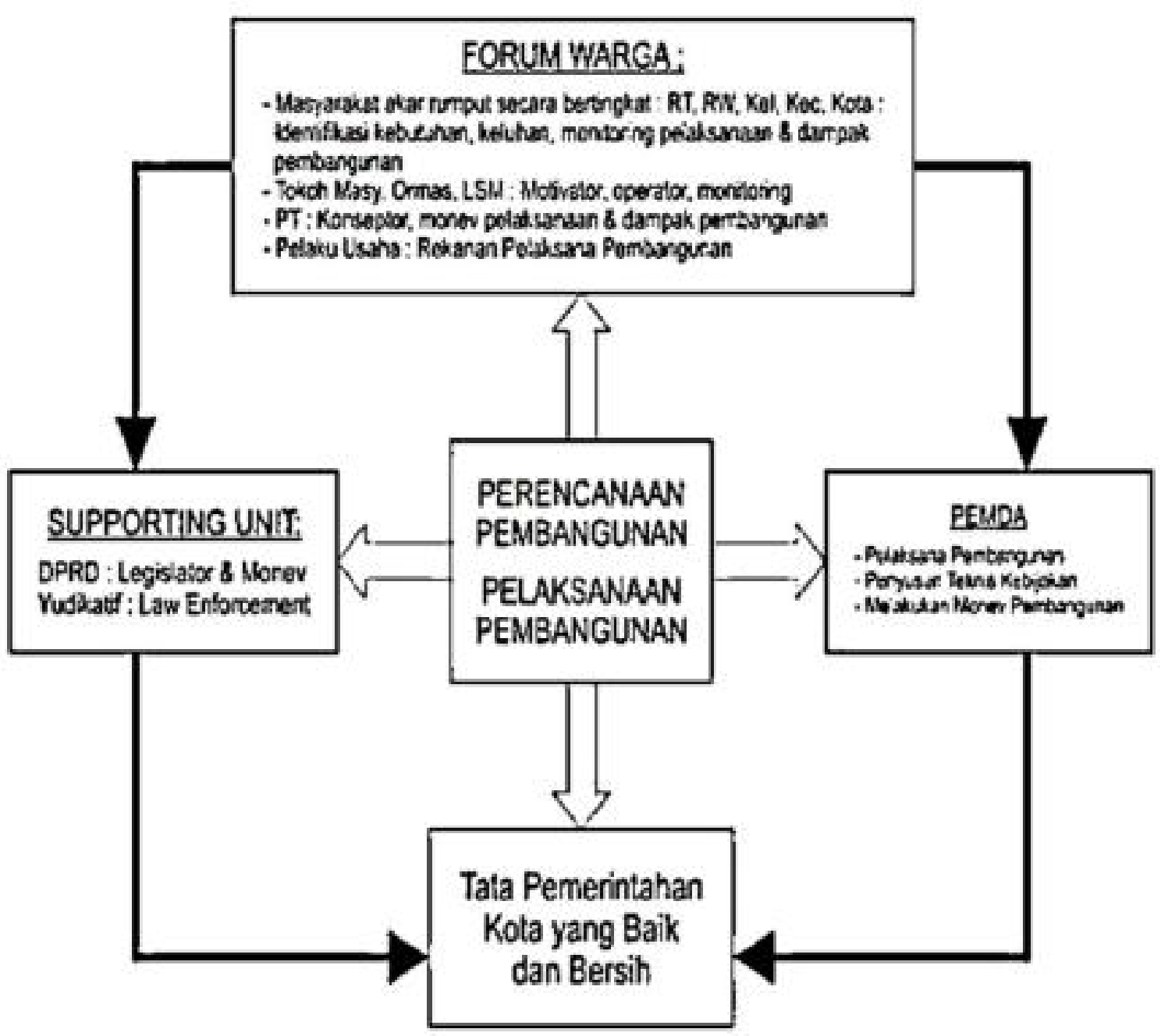

Gambar 01. Diagram Forum Warga dan Jejaring Partisipasi Anggaran (Sumber: Sopanah, 2009) 
Jurnal Pemikiran Sosiologi Volume 5 No. 2, 2018

Jogjaplan dan Kelompok Warga Pengawal Anggaran dalam Perencanaan Pembangunan

di Daerah Istimewa Yogyakarta

Anggalih Bayu Muh. Kamim, M. Rusmul Khandiq, Ichlasul Amal

Forum warga di tingkat desa juga akan mengkoordinasikan rembug warga di tiap kampung sebelum memasuki tahapan musrenbang untuk melakukan identifikasi masalah dan prioritas program yang harus diusulkan oleh warga. Rembug Kampung sebagai bentuk konsolidasi warga penting merupakan bentuk forum adat yang mengkomunikasikan misi besar

pembangunan di DIY. Rembug Kampung yang terselenggara beberapa waktu lalu dari aspirasi yang di sampaikan oleh masyarakat tidak serta merta langsung dapat dianggarkan dalam APBD karena usulan-usulan dari masyarakat hanya dapat diakomodir melalui mekanisme musrenbang. Jika usulan dalam rembug kampung itu ada dalam musrenbang maka usulan-usulan dalam rembug kampung akan memperkuat tingkat kebutuhan dan prioritas pembangunan yang diusulkan oleh masyarakat. Baru kemudian diproses untuk dilakukan sinkronisasi dengan RPJMD, kemampuan fiskal dan kelembagaan SKPD melalui Jogjaplan dan dapat dipantau oleh masyarakat. yang membedakan antara proses perencanaan dan penganggaran yang sebelumnya terletak pada keterlibatan masyarakat pemangku kepentingan (stakeholder yang berkepentingan) dalam bentuk forum warga baik ditingkatan daerah maupun di tingkatan provinsi sampai ditingkatkan pusat. Untuk forum warga juga dibutuhkan koalisi untuk memperjuangkan aspirasi masyarakat berdasarkan tingkat kebutuhan (ibid). 
Jurnal Pemikiran Sosiologi Volume 5 No. 2, 2018

Jogjaplan dan Kelompok Warga Pengawal Anggaran dalam Perencanaan Pembangunan

di Daerah Istimewa Yogyakarta

Anggalih Bayu Muh. Kamim, M. Rusmul Khandiq, Ichlasul Amal

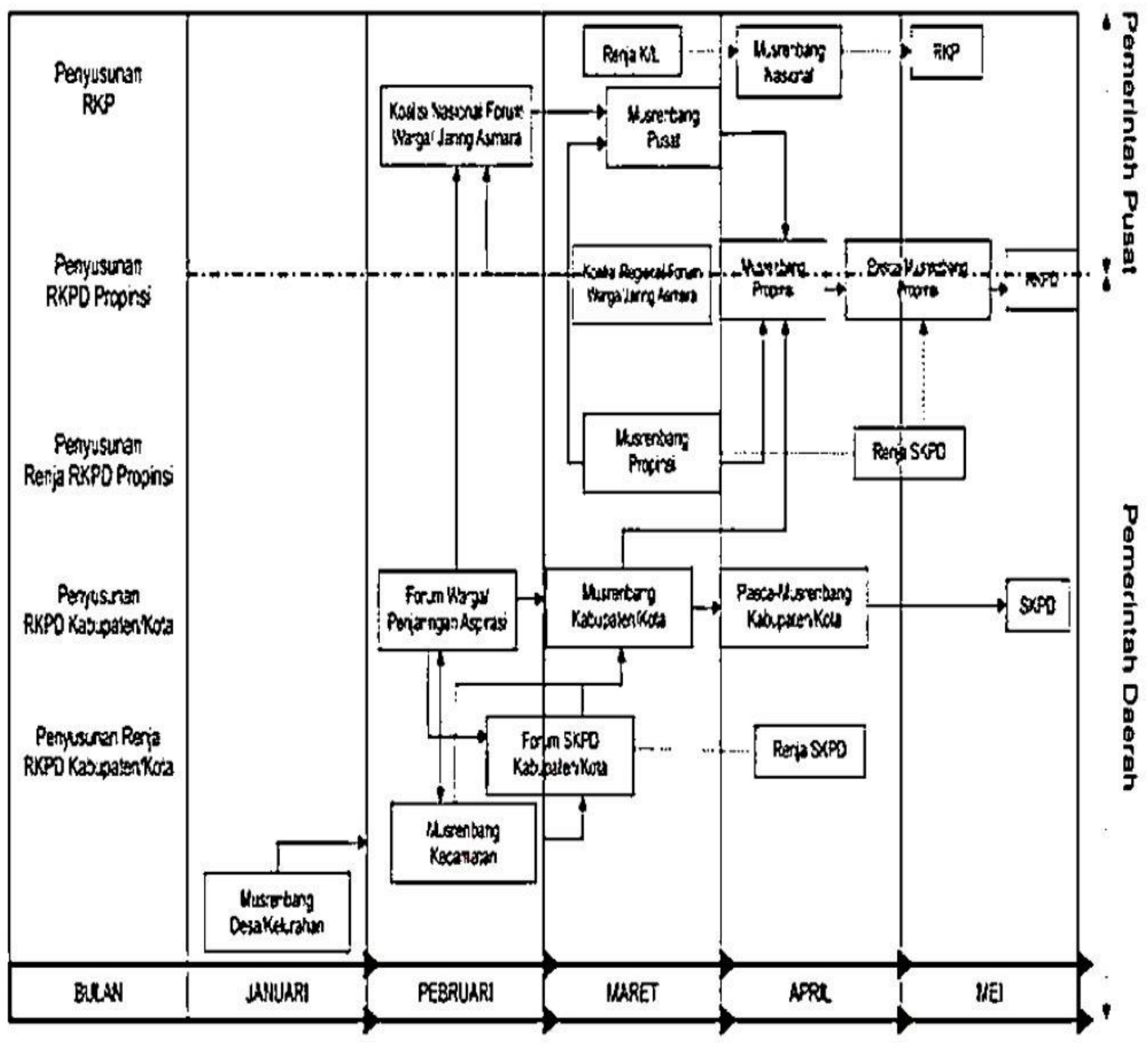

Gambar 02. Alur Perencanaan dan Penganggaran Partisipatif (Sumber: Sopanah, 2009) 
Jurnal Pemikiran Sosiologi Volume 5 No. 2, 2018

Jogjaplan dan Kelompok Warga Pengawal Anggaran dalam Perencanaan Pembangunan

di Daerah Istimewa Yogyakarta

Anggalih Bayu Muh. Kamim, M. Rusmul Khandiq, Ichlasul Amal

Forum warga yang bergerak dalam perencanaan anggaran dan pembangunan ini pada dasarnya bergerak dalam popular space. Popular space, biasanya lebih merupakan arena advokasi warga terhadap penguasa.

Arena ini mungkin untuk diinstitusionalisasikan dengan aturan-aturan main internal yang lebih mengikat. Karena sifatnya lebih merupakan ruang bagi warga, seringkali menunjukan penampakan yang lebih 'agresif'. Menurut Thamrin (2017) advokasi yang dilakukan dalam wahana forum warga ini dapat meliputi:

(a) 'perlawanan' dan 'reaksi' terhadap dimensi relasi kuasa (power relationship) dari berbagai level dengan menjadikan masyarakat sebagai penentu kunci kebijakan publik, mulai dari personal ke domain publik (aspek gender misalnya), dari tingkatan keluarga ke tingkatan pemerintahan;

(b) Penguatan institusi/kelembagaan yang dapat mengartikulasi kelompok-kelompok marginal;

(c) 'menciptakan' dan membuka peluang dalam sistem ekonomi-politik-budaya untuk dilakukan transformasi ke arah yang lebih egaliter;

(d) mengembangkan strategi-strategi penguatan dan pemanfaatan pengetahuan dan keahlian serta kesempatan untuk mempengaruhi pembentukan kebijakan publik;

(e) menjembatani aktifitas dan ekspresi kebijakan makro dan mikro secara timbal balik;

(f) mengadopsi dan mengimplementasikan perjanjian/UU/konstitusi/kesepakatan/perat uran konvensi internasional, nasional, regional dan lokal.

Tugas dari keberadaan LSM dan Perguruan tinggi dalam forum warga sebatas memberikan pendampingan dan penguatan kapasitas. LSM dan perguruan tinggi memperkuat kapasitas warga dalam 4 area, yaitu; menjalankan Musrenbang, membaca dan menganalisis APBD, melakukan monitoring dan penelusuran belanja daerah, melakukan monitoring pelayanan publik. Langkah yang dilakukan forum warga adalah dengan menyelenggarakan rembug warga di tingkat kampung untuk pengembangan partisipasi masyarakat dalam perencanaan daerah. Rembug ini dipergunakan untuk mengidentifikasi masalah dan tantangan partisipasi masyarakat dalam Musrenbang. Kegiatan seperti ini memberikan kontribusi bagi rembug, dalam merumuskan strategi dan agenda kerja mendorong partisipasi masyarakat sipil. Fokus yang menjadi arena kerja-kerja penguatan partisipasi adalah Musrenbang Desa, Musrenbang Kecamatan, 
Jurnal Pemikiran Sosiologi Volume 5 No. 2, 2018

Jogjaplan dan Kelompok Warga Pengawal Anggaran dalam Perencanaan Pembangunan

di Daerah Istimewa Yogyakarta

Anggalih Bayu Muh. Kamim, M. Rusmul Khandiq, Ichlasul Amal

Forum SKPD dan Musrenbang Kabupaten. Pada saat rembug seperti ini, mereka merumuskan strategi untuk bisa terlibat dalam Musrenbang, agenda yang harus diperjuangkan dan pembagian sumberdaya forum warga yang akan didelegasikan. Strategi yang dipilih untuk terlibat dalam Musrenbang adalah merebut "ruang partisipasi". Para delegasi forum warga disebar untuk kembali ke desa atau kecamatan dimana mereka bertempat tinggal. Mereka harus didorong untuk mendaftarkan diri sebagai peserta Musrenbang (Pratiwi, 2012).

Edukasi, agar warga sadar pentingnya peran dan partisipasi mereka dalam pembangunan. Dari penonton pasif menjadi partisipan aktif dan mandiri. Selain itu warga juga perlu dilatih untuk bisa melakukan survei sederhana mengenai prioritas kebutuhan. Strategi pengorganisasi juga harus dilakukan secara kolektif. Warga harus saling berjejaring, terhubung dalam komitmen yang sama dan bergerak serentak. Penulis menyadari bahwa ada banyak organisasi dan kelompok warga seperti PKK, kader posyandu, kelompok tani, kelompok nelayan dan organisasi/paguyuban lainnya. Potensi ini perlu dimanfaatkan agar proses pengumpulan kebutuhan kolektif berjalan dengan baik dan warga dapat bergerak bersama untuk memastikan agar kebutuhan mereka terakomodir dalam program pembangunan daerah.

Dengan adanya survei oleh warga, warga memiliki dasar yang kuat ketika menyusun program pembangunan daerah. Hal terpenting adalah melalui survei oleh warga ini, warga dapat menghadirkan kepentingan kolektif mereka secara utuh dalam forum perencanaan pembangunan agar bisa diakomodir dalam beragam programprogram pembangunan daerah. Sehingga program-program tersebut dapat memenuhi kebutuhan sejati warga. Bisa mengatasi masalah mereka dan memberdayakan potensi mereka (cakrawikara.id, 11 Agustus 2017). Manfaat yang bisa dirasakan oleh warga antara lain: Pertama, mengatasi hambatan kehadiran warga dalam forum musyawarah, karena data diperoleh secara ilmiah dan representatif dari berbagai unsur masyarakat. Survei juga menghadirkan data alternatif pembangunan dan kondisi warga dari pengalaman keseharian warga. Sehingga kebutuhan warga bisa dihadirkan dalam forum perencanaan pembangunan daerah.

Hasil survei juga bisa jadi referensi perencanaan pembangunan daerah,ketika warga berhadapan dalam forum musyawarah dengan pemerintah daerah dan pihak- pihak lainnya (pengusaha, calon legislatif, pengelola CSR,dll). Survei oleh warga dapat mendorong 
Jurnal Pemikiran Sosiologi Volume 5 No. 2, 2018

Jogjaplan dan Kelompok Warga Pengawal Anggaran dalam Perencanaan Pembangunan

di Daerah Istimewa Yogyakarta

Anggalih Bayu Muh. Kamim, M. Rusmul Khandiq, Ichlasul Amal

agar kebutuhan warga dipandang sebagai sebagai kebutuhan bersama bukan pribadi. Dengan demikian warga terlatih untuk membedakan kebutuhan pribadi dan kebutuhan bersama. Survei ini membuka jalan warga untuk berpartisipasi dalam perencanaan pembangunan mulai dari pemetaan kebutuhan, diskusi perencanaan pembangunan dan pemantauan pelaksanaan pembangunan.

\section{F. Kesimpulan}

Pemanfaatan platform Jogjaplan

dilatarbelakangi untuk memudahkan sinkronisasi sekaligus evaluasi perencanaan program dan anggaran pembangunan pada tiap Satuan Kerja Pemerintah Daerah (SKPD) serta berusaha melibatkan masyarakat dalam proses perencanaan anggaran. Namun, sayangnya proses partisipasi yang muncul dalam penggunaan platform Jogjaplan belum menunjukan hasil yang baik dan hanya sebatas pada aspek transparansi. Persoalan partisipasi masyarakat dalam perencanaan pembangunan dan anggaran melalui Jogjaplan juga masih minim. Hal ini ditunjukan dengan minimnya pengakses Jogjaplan. Minimnya pengakses jogjaplan.com ditengarai karena kurangnya sosialisasi, permasalahan literasi digital dan pembangunan sarana penunjang yang belum baik. Dalam konteks birokratis, pemanfaatan platform daring seperti Jogjaplan sendiri memiliki banyak masalah. Umumnya, masalah sumber daya manusia muncul dalam kebijakan perencanaan pembangunan, manajemen keuangan, dan manajemen sumber daya manusia.

Langkah yang dilakukan kelompok warga pengawal anggaran melalui forum warga adalah dengan menyelenggarakan rembug warga di tingkat kampung untuk pengembangan partisipasi masyarakat dalam perencanaan daerah. Rembug ini dipergunakan untuk mengidentifikasi masalah dan tantangan partisipasi masyarakat dalam Musrenbang. Dengan demikian, pelibatan melalui pembentukan kelompok masyarakat pengawal pembangunan dan anggaran di akar rumput pada level desa dapat membantu keberlanjutan serta dukungan terhadap proses pembangunan, karena muncul perasaan kepemilikan bersama terhadap program pembangunan. 
Jurnal Pemikiran Sosiologi Volume 5 No. 2, 2018

Jogjaplan dan Kelompok Warga Pengawal Anggaran dalam Perencanaan Pembangunan

di Daerah Istimewa Yogyakarta

Anggalih Bayu Muh. Kamim, M. Rusmul Khandiq, Ichlasul Amal

\section{Daftar Pustaka}

Abady, Aryaty Puspasari. "Perencanaan Partisipatif Dalam Pembangunan Daerah," Jurnal Otoritas, Vol. III, No.1 (April 2013): 25-34.

Ardin."Pengaruh Penganggaran Partisipatif dan Tekanan Anggaran Terhadap Senjangan Anggaran Dengan Locus of Control Sebagai Variabel Moderasi (Studi Pada Satuan Kerja Perangkat Daerah Kota Palu)." Jurnal Katalogis, 5 (3) (Maret 2017): 22 - 32.

Asare, K. 2012. Community Monitoring and Participatory Budgeting to Promote Accountable Governance in 10 Schools in Ghana. Twiso Praso: ARE Ghana Project.

Ashari, Masjudin; Wahyunadi dan Hailuddin. 2015. "Analisis Perencanaan Pembangunan Daerah Di Kabupaten Lombok Utara (Studi Kasus Perencanaan Partisipatif Tahun 20092013)," Jurnal Ekonomi \& Kebijakan Publik, Vol. 6, No. 2 (Desember 2015): $163-180$.

Azhar, K., Huseini, M., Anwar, R., \& Siong, B.N. 2015. Merekonstruksi Indonesia: Sebuah Perjalanan Menuju Dynamic Governance. Jakarta: Kompas.

Badan Pengawasan Keuangan dan Pembangunan. 2016. "RKP 2016: Pemerintah Fokus pada Infrastruktur." Badan Pengawasan Keuangan dan Pembangunan (Penyunting). Dalam Peningkatan Kapabilitas APIP untuk Mengawal Akuntabilitas Pembangunan Nasional. Warta Pengawasan, Vol. XXII/Edisi HUT Ke 32 BPKP: 16-18.

Goldfrank, B. 2012."'The World Bank and the globalization of participatory budgeting." Journal of Public

Deliberation, 8(2): 1-12.

Hagelskamp, C. et. al. 2016. Why Let the People Decide? Elected Officials on Participatory Budgeting. San Francisco: Public Agenda dan The Kettering Foundation.

Junanto, Deny. 2017. "The Use Of Performance Information In The Indonesian Public

Sector: The Role of Rational/Technocratic And Political/Cultural Frameworks." Disertasi. Birmingham: University of Birmingham.

Kementerian Pendayagunaan Aparatur Negara dan Reformasi Birokrasi. 2015. Top 99 Inovasi Pelayanan Publik Indonesia Tahun 2015. Jakarta:

Kementerian Pendayagunaan Aparatur Negara dan Reformasi Birokrasi.

Kurnia, Novi dan Santi Indra Astuti. 2017. "Peta Gerakan Literasi Digital di Indonesia: Studi Tentang Pelaku, Ragam Kegiatan, Kelompok Sasaran Dan Mitra," INFORMASI Kajian Ilmu Komunikasi, Volume 47. Nomor 2 (Desember 2017):149-166.

Leighninger, M. \& Rinehart, C. 2016. Power of the People and Setting for Using it Wisely? San Francisco: Public Agenda and The Kettering Foundation.

Miyanto, Fitro dan Sugi Rahayu. 2017. "Efektivitas Penerapan Website Jogjaplan.Com Pada Bappeda Daerah Istimewa Yogyakarta," Jurnal Adinegara, Vol.6, No.7: 705-716.

Participatory Budgeting Project. 2017. Participatory Budgeting Project Annual Report 2016 - 2017. Brooklyn: Participatory Budgeting Project. 
Jurnal Pemikiran Sosiologi Volume 5 No. 2, 2018

Jogjaplan dan Kelompok Warga Pengawal Anggaran dalam Perencanaan Pembangunan

di Daerah Istimewa Yogyakarta

Anggalih Bayu Muh. Kamim, M. Rusmul Khandiq, Ichlasul Amal

Pemerintah Daerah DIY. 2015. Laporan Kinerja Pemerintah DIY Tahun 2015. Yogyakarta: Pemerintah Daerah DIY.

Pratiwi, Poerwanti Hadi. 2012. "Perencanaan Partisipasi Lokal: Pengalaman Advokasi." Komunitas, 4 (1): 27-35.

Röcke, Anja. 2014. Framing Citizen Participation: Participatory Budgeting in France, Germany and the United Kingdom. New York: Palgrave Macmillan.

Sopanah. 2009. "Model Pengembangan Partisipasi Masyarakat Dalam Proses Penyusunan Anggaran Pendapatan dan Belanja Daerah," Makalah disampaikan pada Konferensi Penelitian Keuangan Sektor Publik II Badan Litbang Departemen Dalam Negeri di Hotel Bidakara pada 2-3 Juni 2009.

Souza, C. 2001, April. "Participatory Budgeting in Brazilian Cities: Limits and Possibilities in Building Democratic Institutions." Environment \& Urbanization, 13 (1): 159 - 184.

Thamrin, Djuni. 2017. "Membuka Ruang Baru Demokrasi Partisipatif bagi Community Policing: Peran Forum Warga," Jurnal Keamanan Nasional, Vol. III, No.1 (Mei): 63-83.

Wampler, B. 2007. Participatory budgeting in Brazil: Contestation, Cooperation, and Accountability. Pennsylvania : Pennsylvania State University Press

Widodo, S. 2016."Penganggaran Partisipatif dan Pemberdayaan Partisipasi Masyarakat." Buletin APBN, 20 (I): 2 5.

Yunas, N. S. 2017)."Efektivitas E-Musrenbang di Kota Surabaya dalam Sistem Perencanaan Pembangunan Berparadigma Masyarakat." Otoritas:
Jurnal Ilmu Pemerintahan, 7(1): Hlm 19- 27.

Sumber Internet

Astiti, A.A. Sri. 2015. "Inovasi “Jogjaplan" Provinsi Daerah Istimewa Yogyakarta." [Online]. (http://inovasi.lan.go.id/uploads/do wnload/1485745485_1.- STORYLINEJOGJAPLAN-by-A.A.-Sri-Astiti.pdf) Diakses pada 15 Juli 2018.

"BPS 2016: Indeks Pembangunan Teknologi Informasi Indonesia Masih Rendah." (https://tirto.id/bps-indekspembangunan-teknologi-informasiindonesia- masih-rendah-cBMZ) Diakses pada 27 Juli 2018.

"Danais Tidak Boleh Tumpang Tindih.". (https://www.koranbernas.id/danais -tidak-boleh-tumpang-tindih/). Diakses pada Diakses pada 25 Juli 2018.

"Case Studies : Govanhill, Scotland." (https://www.local.gov.uk/govanhillglasgow). Diakses pada 27 Juli 2018

"Indeks pembangunan TIK menurut provinsi." (https://lokadata.beritagar.id/chart/ preview/indeks-pembangunan-tikmenurut-provinsi- 1487126436). Diakses pada 27 Juli 2018.

"JOGJAPLAN (e-Planning)."

(http://bappeda.jogjaprov.go.id/prod uk/detail/Aplikasi-Perencanaan).

Diakses pada 25 Juli 2018.

$$
\text { "Menpan RB Kepincut E- }
$$
Government DIY." (http://jateng.metrotvnews.com/pers tiwa/lKY1Q7oK-menpan-rb-kepincute-government- diy). Diakses pada 25 Juli 2018

“Pemanfaatan Jogjaplan Belum Maksimal." 
(http://www.satuharapan.com/readdetail/read/pemanfaatan-jogjaplanbelum-maksimal). Diakses pada 27 Juli 2018.

"Revolusi Mental Ala DIY." (http://kaltimbkd.info/index.php/id/ berita-dan-artikel/beritaumum/3721-revolusi-mental-aladiy). Diakses pada 25 Juli 2018.

“The 'Citizen Budgets' of Africa Make Governments More Transparent". (https://theconversation.com/thecitizen-budgets-of-africa-makegovernments-more- transparent58275). Diakses pada 25 Juli 2018

"Survei oleh Warga: Perencanaan Partisipatif untuk Mengatasi Ketimpangan." (http://cakrawikara.id/2017/08/sur vei-oleh-warga-perencanaanpartisipatif- untuk-mengatasiketimpangan/). Diakses pada 27 Juli 2018

"Usulan Program Keistimewaan Online Masih Nol."

(http://jogja.tribunnews.com/2014/0 9/04/usulan-program-keistimewaanonline-masih-nol). Diakses pada 25 Juli 2018 